\title{
Design and construction of an Alfa Type Stirling Engine as a teaching prototype
}

\section{Diseño y construcción de un Motor Stirling Tipo Alfa como prototipo didáctico}

PÉREZ-GONZÁLEZ, Marco Antoniơ๋*, PÉREZ-GUTIÉRREZ, Alma Noemí, RAMÍREZVILLASEÑOR, Edgar Noel and GONZALEZ-LOPEZ, Juan Miguel

Universidad de Colima

ID $1^{\text {st }}$ Author: Marco Antonio, Pérez-González / ORC ID: 0000-0002-5603-7553, arXiv Author ID: marcoperezarxiv, CVU CONACYT: 91422

ID $1^{\text {st }}$ Coauthor: Alma Noemí, Pérez-Gutiérrez / ORC ID 0000-0002-1177-0890, arXiv Author ID: NOEMI_PEREZ, CVU CONACYT: 345102

ID $2^{\text {nd }}$ Coauthor: Edgar Noel, Ramírez-Villaseñor / ORC ID: 0000-0002-8775-5670, arXiv Author ID: 346230

ID $3^{\text {rd }}$ Coauthor: Juan Miguel, Gonzalez-Lopez / ORC ID: 0000-0002-1795-3903, Researcher ID Thomson: H-94052018, CVU CONACYT ID: 54012

\section{Abstract}

This paper shows the design and construction of a Stirling engine prototype as an alternative to generate electricity as well as a teaching tool to be used with mechanical electrical engineering students. The engine will be coupled with a DC generator feeding a LED. The projected outcome power is $6 \mathrm{~W}$ at a $12 \mathrm{~V}$ operation level.

Alpha-type Stirling engine, Stirling Cycle, Piston

\section{Resumen}

En este artículo se presenta la experiencia obtenida con el proyecto diseño y construcción de un Motor Stirling tipo Alpha, como una alternativa de generación de energía eléctrica y una herramienta de apoyo didáctico para estudiantes de la carrera Ingeniero Mecánico Electricista. El prototipo desarrollado se acoplará con un generador CD el cual alimenta a una carga eléctrica, en este caso un led. La potencia esperada es de $6 \mathrm{~W}$ operando a una tensión nominal de $12 \mathrm{~V}$.

Keywords: Motor Stirling tipo alpha, Ciclo Stirling, Pistón

Citation: PÉREZ-GONZÁLEZ, Marco Antonio, PÉREZ-GUTIÉRREZ, Alma Noemí, RAMÍREZ-VILLASEÑOR, Edgar Noel and GONZALEZ-LOPEZ, Juan Miguel. Design and construction of an Alfa Type Stirling Engine as a teaching prototype. ECORFAN Journal-Democratic Republic of Congo. 2019, 5-8: 7-13.

\footnotetext{
* Correspondence to Author (email: marcoperez@ucol.mx)

$\dagger$ Researcher contributing first author.
} 


\section{Introduction}

The Stirling engine is a thermal machine with low noise levels and toxic emissions. This engine can use any external energy source (solid, liquid and gaseous fuels, nuclear energy, solar, geothermal sources, etc.), reaching zero emissions when using solar energy. In the near future, these engines will probably have different applications, even including replacing internal combustion engines in some applications. (Agüero V., 2006)

The thermal efficiency of a well-designed Stirling engine is relatively high (Khaled et al, 2018). Due to the characteristic of obtaining heat from an external source, this motor is a good option to take advantage of thermal sources that are the waste or waste of other processes (Ahmad et al, 2017) and (Asnaghi et al, 2012).

\section{Theoretical Foundation}

The work is obtained by expanding the hot gas confined to high pressure. To complete the cycle, the gas cools before being compressed to begin the next cycle. The main components of the Stirling engine are; the heat source, heater, regenerator, cooler, piston / displacer and chambers. Heat transfer processes are the key parameters that affect engine performance. The effectiveness of the regenerator has a strong effect on the performance of the Stirling engine Khaled et al, 2018).

The gap between the two pistons causes the air to pass from one cylinder to another by heating or cooling and performing the work that allows the operation of the motor as shown in the figure. one.

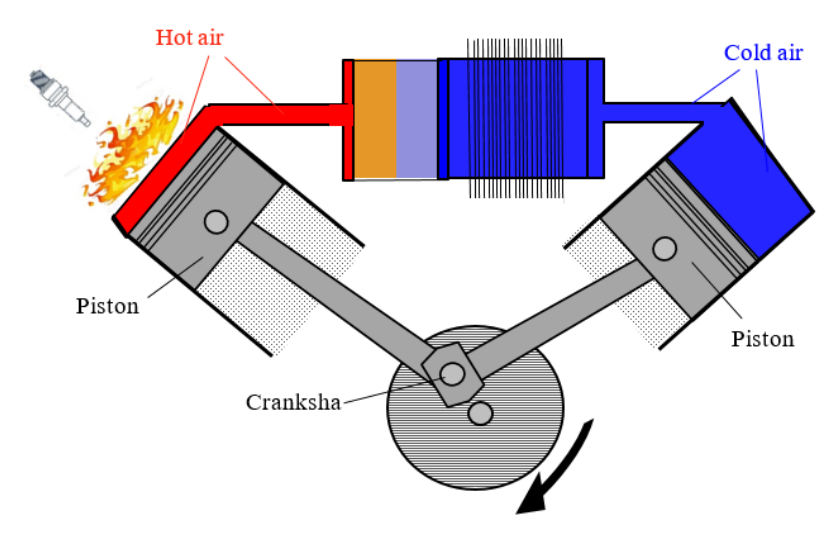

Figure 1 Operation of Stirling Engine

(http://motorstirlingyadyrtecsup.blogspot.com/)
This type of motors are also called hot air motors. This term is given to the thermal machines that make use of the expansion and compression of air under the influence of a change of temperatures, having a high temperature reservoir and a low temperature reservoir, it manages to convert the thermal energy of itself into mechanical energy. As shown in figure 2 .

In this type of engine, the air is heated and cooled repeatedly inside the cylinder, such effect produces an expansion and compression of the air causing the movement of the piston; thus producing useful work. There are different types of air motors, among which we can highlight: Motor Carnot, Motor Ericsson, Motor Stirling.

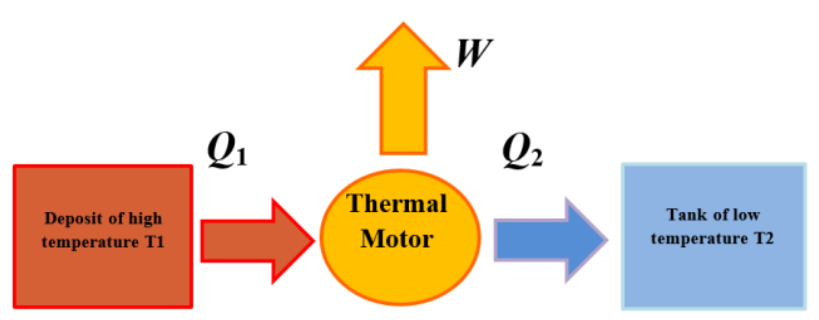

Figure 2 Diagram of a hot air motor that produces mechanical energy (W), by a temperature difference (http://motorstirlingyadyrtecsup.blogspot.com/)

\section{Carnot engine or carnot cycle}

In 1824 Sadi Carnot studied the efficiency of the different thermal machines that work transferring heat from one source of heat to another and concluded that the most efficient machines are those that work in a reversible manner. For this he designed a fully reversible thermal machine that works between two heat sources of fixed temperatures. This machine is known as the Carnot machine and the basis of its operation is called the Carnot cycle, whose main characteristics are shown in figure 3 .

Inequality $\quad f \frac{d Q}{d t} \leq 0$ represents the Clausius Theorem and only applies to the ideal cycle or Carnot cycle. Since the integral represents the net change in entropy in a complete cycle, the most efficient motor cycle is attributed a zero entropy change. The Clausius inequality applies to any real cycle motor and assumes a negative change in entropy for the cycle. 
That is, the entropy given to the environment during the cycle is greater than the entropy transferred by the heat from the hot focus to the motor. In the simplified heat engine, where all the heat $\mathrm{QH}$ is added to the temperature $\mathrm{TH}$, then to complete the cycle an amount of entropy $\Delta \mathrm{S}=\mathrm{QH} / \mathrm{TH}$, which is obtained from the environment, is added to the system. In general, the engine temperature will be less than $\mathrm{TH}$ at least during the part of the time when heat is being added, and any temperature difference is an irreversible process. In any irreversible process an excess of entropy is created, and therefore more heat must be thrown to the cold focus, to get rid of this entropy. This leaves less energy to do work.
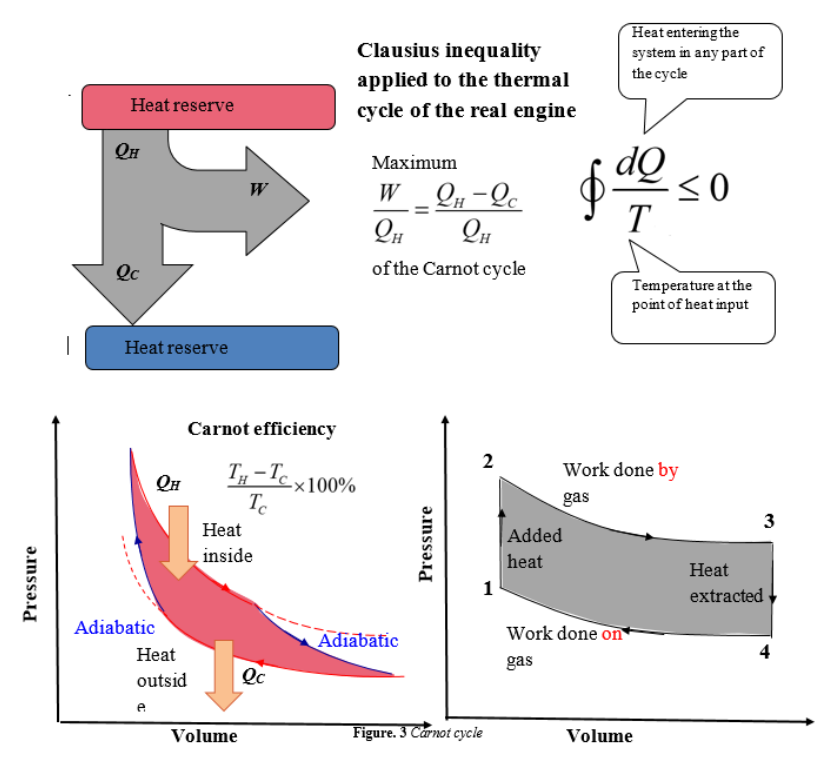

Figure 3 Carnot cycle

(http://hyperphysics.phy-

astr.gsu.edu/hbasees/thermo/clausius.html)

The Carnot cycle is an ideal thermodynamic cycle reversible between two temperature sources, in which the maximum performance is. The cylinder contains a certain amount of ideal gas and the machine works by exchanging heat between two constant temperature sources $T_{H}>T_{C}$. The heat transfers between the sources and the cylinder gas are made isothermally, that is, keeping the temperature constant, which makes that part of the process reversible.

Engine performance is defined by expression:

$\eta=\frac{T_{H}-T_{C}}{T_{H}}$
$\eta=1-\frac{T_{C}}{T_{H}}$

How is observed from the expression (2) the efficiency relates the hot and the cold temperature. Therefore, the lower this ratio, that is, the higher the $T_{H}$ with respect to $T_{C}$, the better the efficiency.

\section{Stirling cycle}

The basic principle of the Stirling engine consists of a gas enclosed in an airtight cylinder that has a hot end and a cold end. Inside the cylinder is a displacement piston and a power piston. The purpose of the power piston is to prevent the gas from escaping and to transmit the work to the outside of the cylinder. The function of the displacer is to make the air move from the cold to the hot zone and vice versa.
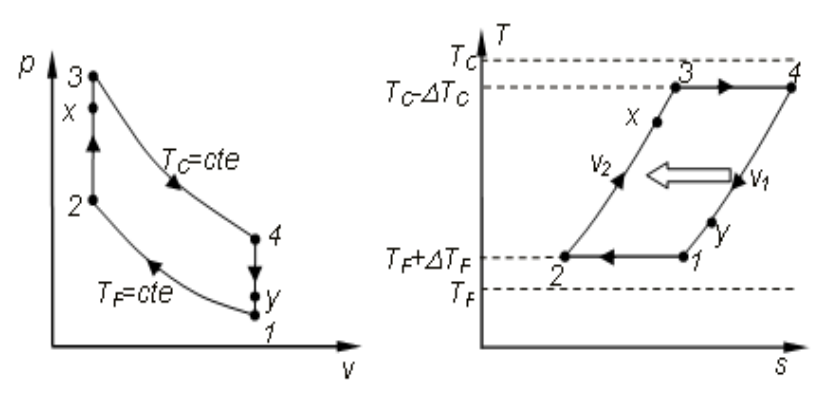

Figure 4 Stirling cycle

(González-Baylon et al, 2011)

The gas is displaced towards the hot part of the cylinder expands increasing the internal pressure which allows to obtain work. Then the gas is displaced to the cold part where its temperature drops and the pressure decreases. The cycle consists of four processes as shown in figure 3, two isometric processes in which the gas passes through the regenerator absorbing or yielding heat and two isothermal processes in which the gas is in contact with a high temperature reservoir $\left(\mathrm{T}_{\mathrm{H}}\right)$ or one of cold temperature $\left(\mathrm{T}_{\mathrm{C}}\right)$.
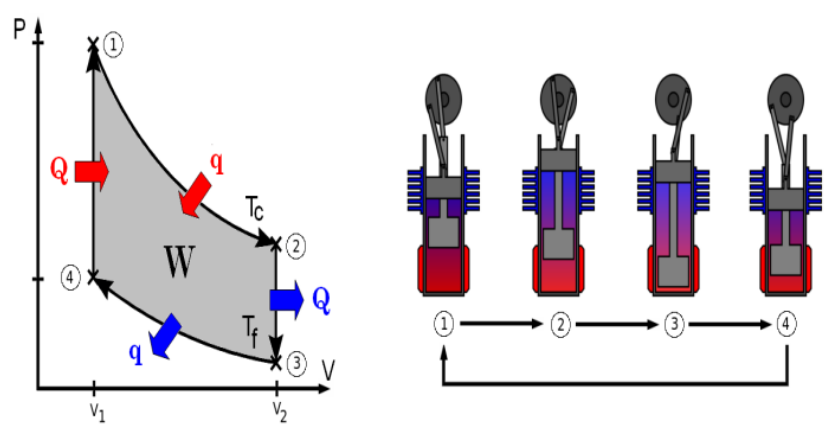

Figure 5 Stirling engine performance

PÉREZ-GONZÁLEZ, Marco Antonio, PÉREZ-GUTIÉRREZ, Alma Noemí, RAMÍREZ-VILLASEÑOR, Edgar Noel and GONZALEZLOPEZ, Juan Miguel. Design and construction of an Alfa Type Stirling Engine as a teaching prototype. ECORFAN Journal-Democratic Republic of Congo. 2019. 
At the start of the cycle, the air inside the cylinder is compressed, with high temperature and high pressure (1). These conditions, added to the heat input, cause the air to expand and, through the power piston, perform work moving from volume V1 to volume V2 (2). Immediately after this occurs, the displacement piston rapidly falls to the hot region of the cylinder allowing the temperature and air pressure to drop because it is exposed to the cold region of the cylinder (3). At this point, the flywheel connected to the crankshaft that synchronizes the movement of the power and displacement cylinders carries enough inertia to cause the power piston to work on the system compressing the air (4). Once the power piston reaches the volume $\mathrm{V} 1$, the displacement piston rises rapidly towards the cold region of the cylinder in order that the air is exposed to the hot region of the cylinder and thus increases its temperature and pressure to reach the state initial where the cycle is repeated.

\section{Materials and methods}

The prototype design was developed in a CAD environment, using the Solid Works ® tool. The manufacturing was implemented using the Faculty 's infrastructure, a conventional lathe, conventional milling machine, closing - tape, and welding machine. The materials used, as well as the mechanical elements that make up the design are shown in tabls 1 and 2:

\begin{tabular}{|l|l|}
\hline \multicolumn{1}{|l|}{ Quantity } \\
\hline 1 & $\begin{array}{l}\text { Material } \\
\text { diameter } x 15 \mathrm{~cm} .\end{array}$ \\
\hline 1 & Iron plate $1 / 415 \times 15 \times 1 / 4$ \\
\hline 1 & $\begin{array}{l}\text { Round section of steel 3.5 inches in } \\
\text { diameter x } 10 \mathrm{~cm} \text { thick }\end{array}$ \\
\hline 1.5 & Asparagus meters of $1 / 4$ inch \\
\hline 24 & $1 / 4$ nuts \\
\hline 4 & Toners with nut and $5 / 16$ washer \\
\hline 2 & Thermal packaging 3.5 inches \\
\hline 1 & 40cms plastic hose \\
\hline
\end{tabular}

Table 1 Used material

\begin{tabular}{|l|l|}
\hline \multicolumn{1}{|c|}{ Components Quantity } \\
\hline Container & 1 \\
\hline Pistons & 2 \\
\hline Connecting rod & 2 \\
\hline Crankshaft & 1 \\
\hline Balero & 6 \\
\hline Steering wheel & 1 \\
\hline Electric generator & 1 \\
\hline Pulley & 1 \\
\hline LED bulb 12V-10W & 1 \\
\hline
\end{tabular}

Table 2 Mechanical elements of the prototype
Due to the requirements established in the project protocol, a redundant design was followed, so all the pieces were modeled in both SolidWorks $®$ and AutoCAD $®$ for each of the elements of the prototype.

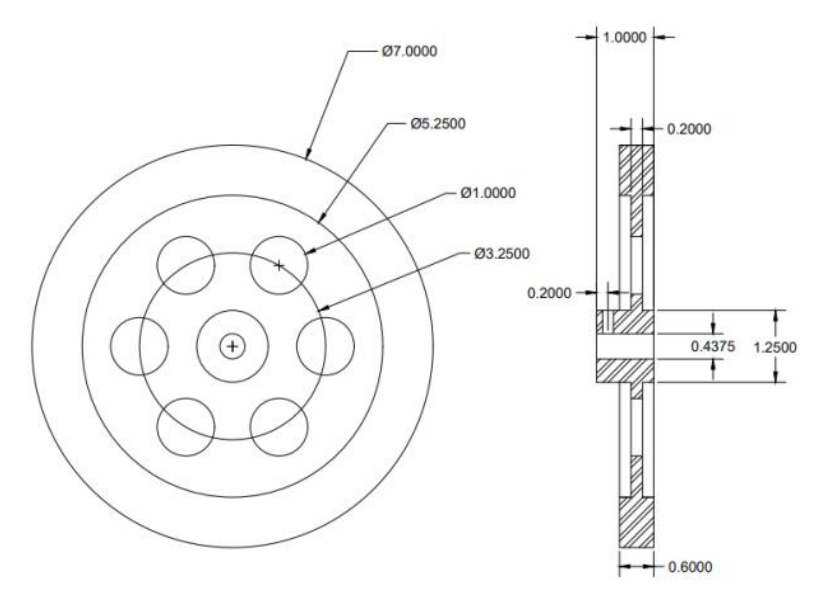

Figure 6 Model of the flywheel with dimensions and designed in AutoCAD

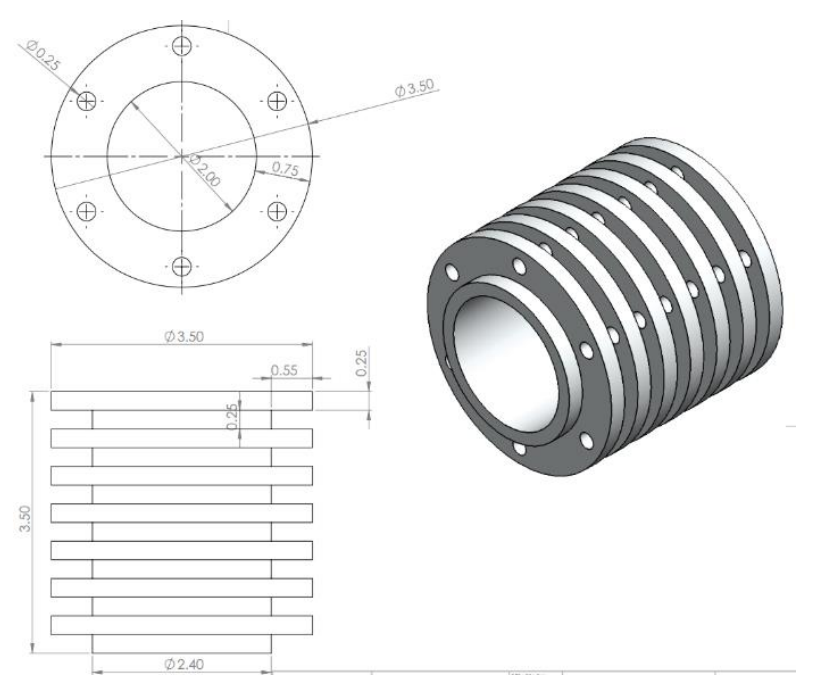

Figure 7 Cooling cylinder model with dimensions and designed in AutoCAD

Figures 6 to 9 show different views of the prototype design. Floor and $3 \mathrm{D}$ views of the flywheel (figures 6 and 8), of the heat sink (figure 7), of the assembled prototype seen from two different angles (figures 8 and 9), as well as details of the connecting rod - crank mechanism (figure 9) to show some of the key elements in the design of this type of thermal machines.
PÉREZ-GONZÁLEZ, Marco Antonio, PÉREZ-GUTIÉRREZ, Alma Noemí, RAMÍREZ-VILLASEÑOR, Edgar Noel and GONZALEZLOPEZ, Juan Miguel. Design and construction of an Alfa Type Stirling Engine as a teaching prototype. ECORFAN Journal-Democratic Republic of Congo. 2019. 


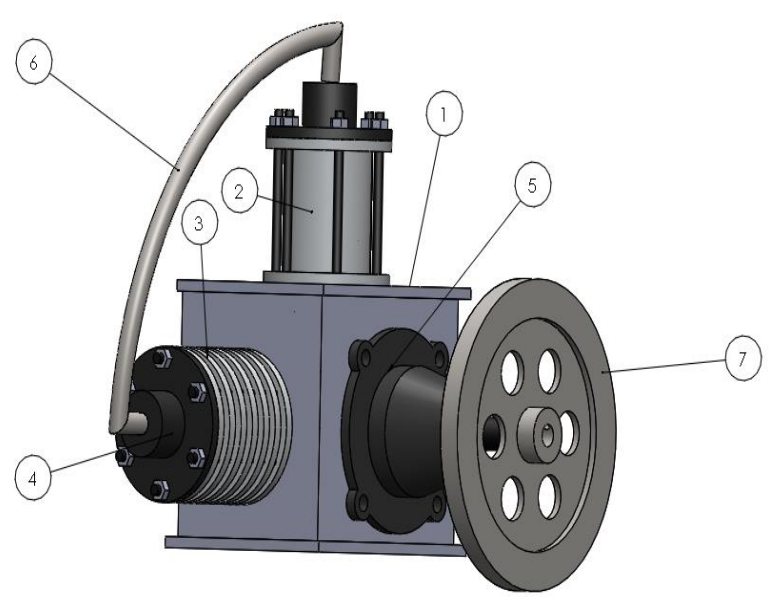

Figura 8 Prototype of the engine in SolidWorks ${ }^{\circledR} .1$. housing. 2. Heating cylinder. 3. Cooling cylinder. 4. Cylinder cover. 5. Crankshaft bearing shaft. 6. Hot-cold connection tube. 7. Flywheel

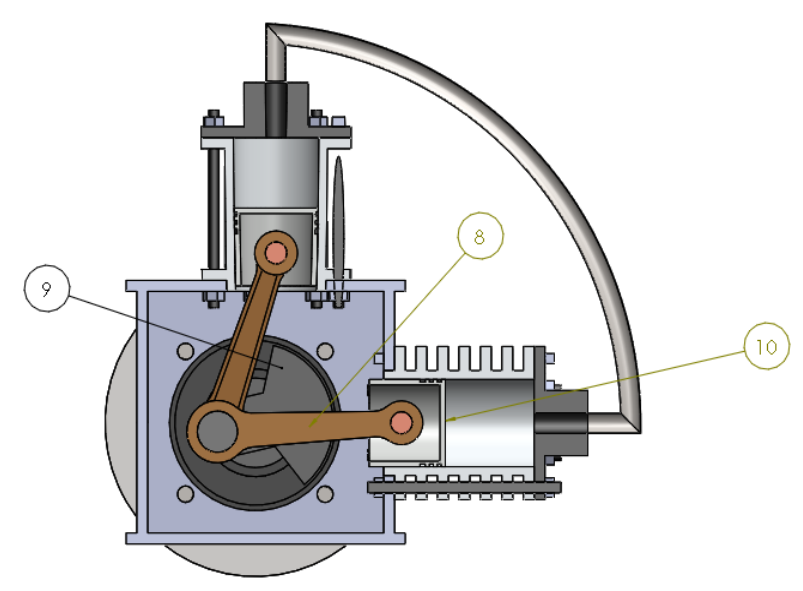

Figure 9 Prototype of the engine in SolidWorks ${ }^{\circledR}$. 8. Connecting rod 9. Crankshaft 10. Piston

Although these models were generated in CAD environment, the manufacturing process was carried out in both conventional and semiautomatic machines. This required making adjustments and a heuristic process that finally were also reflected in the models presented in this paper. Figure 10 shows some aspects of the construction of the prototype using different types of machines and tools.
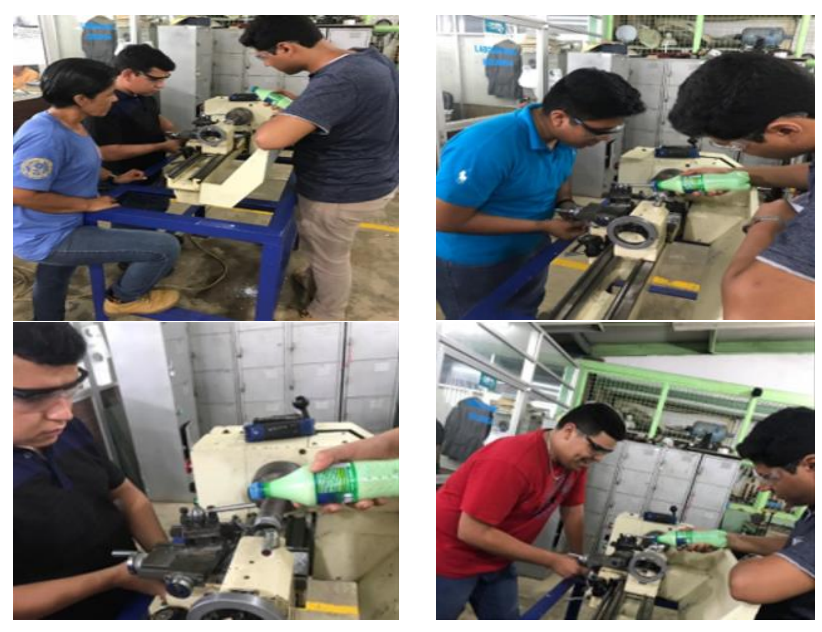

Figure 10 Stage of construction of the prototype in the faculty laboratory

\section{Results}

Every manufacturing process must consider that there will always be a need to make adjustments and changes of any magnitude in the machining technique as well as in the design to seek to ensure that the developed prototype works properly. As (Church et al, 2016, Chen et al, 2014 and Lockhart, et al, 2017) mention, this stage of the project turns out to be the one that presents the most challenges for the fulfillment of delivery dates. During the period assigned for the development of the prototype, the pieces manufactured were analyzed and improved. Once all the parts were manufactured, the engine was assembled, making different tests.

In the tests the movement of the piston turned out to be partial, that is to say, the operation of the engine was not adequate, since after a couple of cycles where the exchange of air was made in both chambers, the movement ceased. Although different solutions were tried, such as material modifications, tolerances and adjustments, it was not possible to achieve continuous operation of the prototype. Among the problems that could be detected, the following are considered:

- Overcoming the inertia of the steering wheel proved to be a challenge, since with the initially supplied energy it was apparently not enough. 
- The piston that admits the air at a lower temperature presented difficulty in the movement, which made difficult the movement of the other that could be moved freely manually.

- There were leaks that were then successfully corrected

- Since piston rings were crucial to seal the cylinder, as well as to reduce metal-tometal contact, this was a problem that needed to be addressed. However, when the diameters of the piston and cylinder rings were measured with the calipers, it was found that the piston and the rings should have a slightly looser fit.

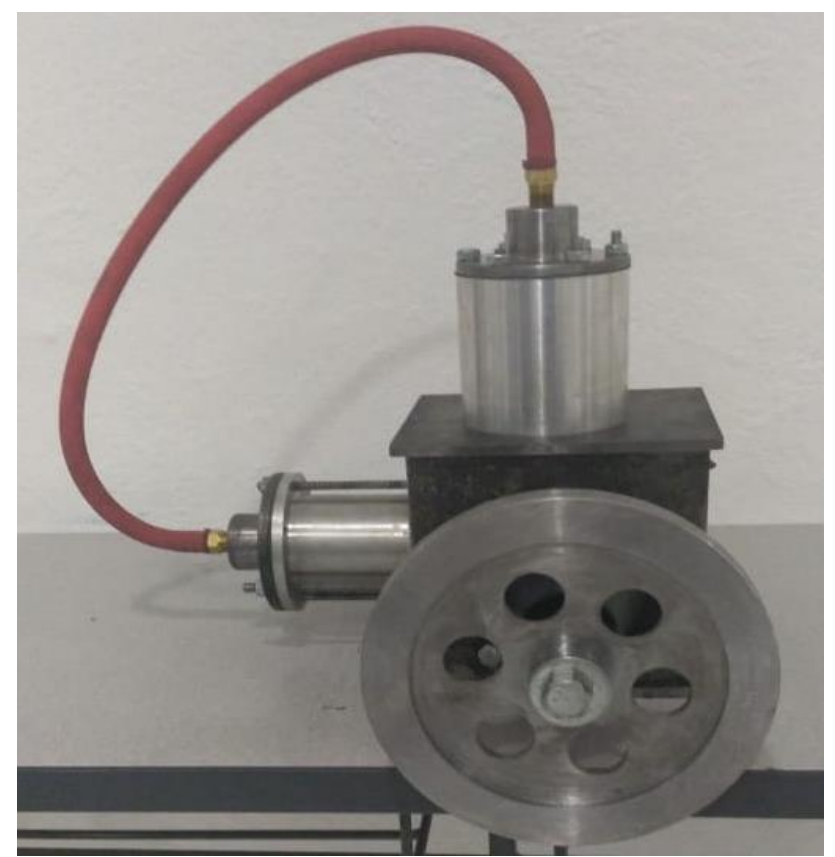

Figure 11 Finished prototype of a Stirling engine previous view

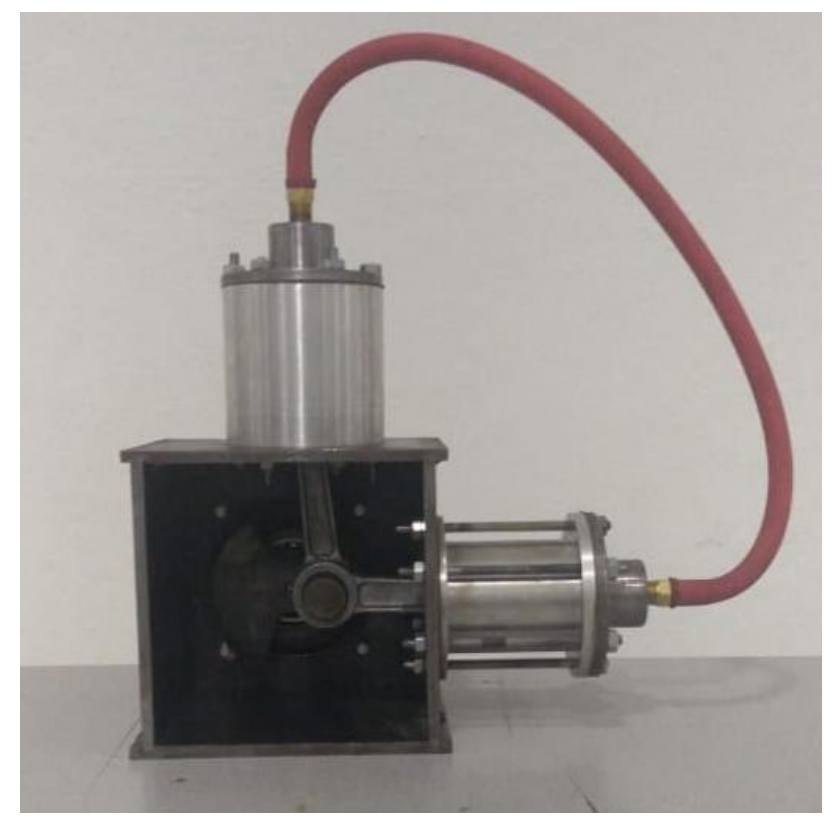

Figure 12 Finished prototype of a Stirling engine rear view
The images shown in figures 11 and 12 show the finished prototype, seen from two different angles. The design of the flywheel is noted, as well as the finishes of the working fluid exchange chambers and the mechanism that allows continuous movement.

\section{Acknowledgments}

To the University of Colima for the support provided for the preparation of this research work among students and academics.

\section{Conclusions}

The authors consider that the experience that the students obtained in the whole process has been of great benefit. At a cognitive level, it allowed students to develop a project from the theoretical conception and fundamentals of operation of the thermal machine. In the practical aspect, the students were able to identify very sensitive aspects in all mechanical metal manufacturing processes, that is, adjustments, tolerances, quality of finishes, relationship between machining speed and finished quality, etc. As well as the design of the virtual instrument that together with the design stage in CAD environment allow the student to interact in a more intense way with the different computational platforms that were used in these stages of the project.

Finally, in the methodological aspect, all the stages of the project pay directly to the understanding of what is a project of these characteristics.

It is necessary that there is a closer feedback between the design and manufacturing processes since the experience achieved indicates that if there is no adequate design no matter how precise the manufacturing and in the same way if the manufacturing is deficient the advantage of having a design optimal is lost.

\section{Future work}

It will work on a redesign that allows to reduce the weight in the flywheel and in the pistons. These can be drilled to obtain "hollow" pistons with or that the weight would drop by a considerable percentage. Make a more precise manufacturing to achieve a more relaxed fit between the pistons and cylinders so that better movement is possible.

PÉREZ-GONZÁLEZ, Marco Antonio, PÉREZ-GUTIÉRREZ, Alma Noemí, RAMÍREZ-VILLASEÑOR, Edgar Noel and GONZALEZLOPEZ, Juan Miguel. Design and construction of an Alfa Type Stirling Engine as a teaching prototype. ECORFAN Journal-Democratic Republic of Congo. 2019. 
Another aspect to consider is to improve the design and type of heat sink material that allows and heat exchange in a more efficient manner. A stage that is considered is to monitor in real time the temperature of the working fluid, the speed of rotation, as well as the instantaneous output power. The aim is to design a virtual instrument in any of the existing computational platforms in order to have a graphical interface that shows in real time the performance of the thermal machine.

\section{References}

Agüero V., "Diseño y construcción de un motor stirling para la generación de energía eléctrica", Tesis Ingenieria Mecanica, Universidad Nacional de Ingeniería, Lima, Perú, 2006.

Ahmad K., Saad M., Raya A., "Modelling and parametric study of an efficient Alpha type Stirling engine performance based on 3D CFD analysis", Energy Conversion and Management, Vol. 145, 1 August 2017, Pp. 93106

Asnaghi, A., Ladjevardi, S., Izadkhast, S., Kashani, A., "Thermodynamics Performance Analysis of Solar Stirling Engines, ISRN Renewable

Energy

Volume 2012", Article ID 321923, 14 pages http://dx.doi.org/10.5402/2012/321923

Chen H., Czerniak S., De La Cruz E., "Design of a Stirling Engine for Electricity Generation", Qualifying Project for the Degree of Bachelor of Science, Worcester Polytechnic Institute, Worcester, England, 2014.

Church A., Greenbaum B., Stirling C., "Stirling Engine Fabrication and Design", Qualifying Project for the Degree of Bachelor of Science, Worcester Polytechnic Institute, Worchester, England, 2016.

González-Baylon, J. Quintero-Cabrera, D., Borrajo-Pérez, R., "Análisis de irreversibilidades en el comportamiento de un motor Stirling", Ingeniería Mecánica vol.14 no.2 La Habana Mayo-ago. 2011, versión Online ISSN 1815-5944

Imagen disponible en http://hyperphysics.phyastr.gsu.edu/hbasees/thermo/clausius.html Imagen disponible en http://motorstirlingyadyrtecsup.blogspot.com/
Khaled M. B., "Numerical thermodynamic model of alpha-type Stirling engine", Case Studies in Thermal Engineering, Vol. 12, September 2018, Pp. 104-116

Lockhart I., "A Perspective on Smart Process Manufacturing Research Challenges for Process Systems Engineers", Engineering, Volume 3, Issue 2, April 2017, Pages 161-165 